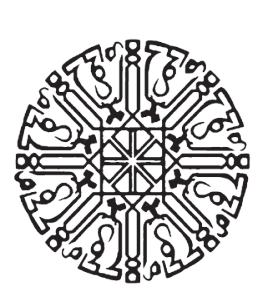

\title{
Kebijakan Formulasi Delik Agama dalam Kitab Undang-Undang Hukum Pidana Yang Baru
}

\author{
Ahmad Hunaeni Zulkarnaen, Kristian, M. Rendi Aridhayandi \\ Universitas Suryakancana Cianjur (UNSUR). \\ ahmadhzul@gmail.com \\ yehezkiel.kristian90@gmail.com \\ mrendiaridhayandi@unsur.ac.id \\ "Pidana itu dijatuhkan bukan karena telah berbuat jahat, \\ tetapi agar jangan berbuat kejahatan...."
}

-Plato dan Aristoteles-

\begin{abstract}
This paper will discuss the formulation policy of religious delict In the new penal code i.e. in the draft book of penal code version of the year 2015. This is important because the first sila of Pancasila as the philosophy of life, soul, views, guidelines and the personality of the nation of Indonesia at once into the philosophy of nation and state as well as being the source of all the sources of law in Indonesia is "The Divinity Of The One True God". This means that Indonesia is one of the country's believe in God and has a deep philosophy of the deity as well as placing the religion as the main joints in the life of society, nation and State. In his position as State of law specifically legal state of Pancasila (as a religious nation state), religion occupies a central position and is essential in the entire life of the community that need to be guaranteed and protected (can not be reduced in the circumstances any) as mandated by the 1945 Constitution as the country's constitution and laws of the Republic of Indonesia No. 39 Year 1999 about human rights and religious harmony even live between people religion (so created an atmosphere of life harmony and mutual respect in the spirit of complexity consolidated the identity and personality of the nation as well as streng then the harmony of life of society, nation and State) are listed as important in the outlines of the bow Country (Garis-Garis Besar Haluan Negara-GBHN). Therefore, it is reasonable if the State entering or making religion as one in the law delict. The settings on this religion is viewed essential delict due to insult (or other means) of a recognized religion in Indonesia could jeopardize peace, harmony, tranquility, welfare (whether material or regeneration), social justice and threatened national stability and durability. Religion can also be a sensitive factor which can destroy the unity and oneness of the nation of Indonesia. On account of
\end{abstract}


these writings were also created as one form of thinking in order to find out the formulated religious delict and weaknesses that exist in it so that in the future, be able to do updates. Beyond the existence of the pros and cons you submitted religious delict in the penal code, the results of the study, indicate that the arrangements regarding the criminal offence against religion and religious life in the draft penal code (RKUHP) refers to the development of "blasphemy", in the United Kingdom or the development "godslasteringswet" in the Netherlands. Criminalization delictreligion in Indonesia is based on the religionsschutz theorie, gefuhlsschutz theorie, and, friedensschutz theorie. In the draft penal code (RKUHP), religious delict formulated in article 8 which are divided into two categories namely: criminal acts Against religion (that includes an insult to religion and provocation to abolish the beliefs of religion) and criminal acts against the life of the Religion and worship (which include the disruption of their service and religious activities and destruction of places of worship). Formulation policy is still much religion delik contains weaknesses so that it will have an effect on the stage of the applications and their execution in the practice of law enforcement in Indonesia. In connection with the use of religion, delict criminal sanctions certainly should pay attention to signs of criminal use and must be carried out with the purpose of doing a special public and prevention. Therefore, the results of this research are expected to be inputs for the formulation of policy refinement the draft penal code (RKUHP) version the year 2015 particularly with regard to religious delict. This research uses the normative legal research methods (the juridical normative) and conduct studies of materials libraries in order to collect the data and conducted secondary interpretation by using the approach to law, comparative law, history the law, principles of law and legal theory.

Keyword: Formulation Policy, The Draft Penal Code, Religious Delict.

\begin{abstract}
Abstrak
Tulisan ini akan membahas kebijakan formulasi delik agama dalam Kitab Undang-Undang Hukum Pidana yang baru yakni dalam Rancangan Kitab Undang-Undang Hukum Pidana versi tahun 2015. Hal ini menjadi penting karena sila pertama dari Pancasila sebagai falsafah hidup, jiwa, pandangan, pedoman dan kepribadian bangsa Indonesia sekaligus menjadi falsafah bangsa dan Negara serta menjadi sumber dari segala sumber hukum di Indonesia adalah "Ketuhanan Yang Maha Esa". Ini berarti, Indonesia adalah salah satu negara berTuhan dan memiliki filosofi Ketuhanan yang mendalam serta menempatkan agama sebagai sendi utama dalam kehidupan bermasyarakat, berbangsa dan bernegara. Dalam kedudukannya sebagai Negara hukum khususnya Negara hukum Pancasila (sebagai religious nation state), agama menempati posisi sentral dan hakiki dalam seluruh kehidupan masyarakat yang perlu dijamin dan dilindungi (tidak dapat dikurangi dalam keadaan apapun) sebagaimana diamanatkan oleh Undang-Undang Dasar 1945 sebagai Konstitusi Negara dan UndangUndang Republik Indonesia No. 39 Tahun 1999 tentang Hak Asasi Manusia bahkan agama dan kerukunan hidup antarumat beragama (sehingga tercipta suasana kehidupan yang harmonis dan saling menghormati dalam semangat kemajemukan, memperkukuh jati diri dan kepribadian bangsa serta memperkuat kerukunan hidup bermasyarakat, berbangsa dan bernegara) dicantumkan sebagai hal yang penting dalam Garis-Garis Besar Haluan Negara (GBHN). Oleh karena itu, wajar jika Negara memasukan atau menjadikan agama sebagai
\end{abstract}

al-aḥkām vol. 3, Nomor 1, 2018 
salah satu delik didalam hukum positifnya. Pengaturan mengenai delik agama ini dipandang penting karena penghinaan (atau cara-cara lainnya) terhadap suatu agama yang diakui di Indonesia dapat membahayakan perdamaian, kerukunan, ketentraman, kesejahteraan (baik secara materil maupun spirituil), keadilan sosial dan mengancam stabilitas dan ketahanan nasional. Agama juga dapat menjadi faktor sensitif yang dapat menghancurkan persatuan dan kesatuan bangsa Indonesia. Atas alasan tersebut juga tulisan ini dibuat sebagai salah satu sumbangsih pemikiran dalam rangka mengetahui rumusan delik agama dan kelemahankelemahan yang ada didalamnya sehingga dimasa yang akan datang, dapat dilakukan pembaharuan. Diluar adanya pro-kontra dimasukannya delik agama dalam Kitab UndangUndang Hukum Pidana yang baru, Hasil penelitian, menunjukan bahwa pengaturan mengenai tindak pidana terhadap agama dan kehidupan beragama dalam Rancangan Kitab UndangUndang Hukum Pidana (RKUHP) mengacu kepada perkembangan "blasphemy" di Inggris atau perkembangan "Godslasteringswet" di Belanda. Kriminalisasi delik agama di Indonesia didasarkan pada religionsschutz theorie (teori perlindungan agama), gefuhlsschutz theorie (teori perlindungan perasaan keagamaan) dan friedensschutz theorie (teori perlindungan perdamaian atau teori perlindungan ketentraman umat beragama). Dalam RKUHP, delik agama ini dirumuskan dalam 8 pasal yang terbagi menjadi 2 kategori yakni: Tindak Pidana Terhadap Agama (yang mencakup penghinaan terhadap agama dan penghasutan untuk meniadakan keyakinan terhadap agama) dan Tindak Pidana Terhadap Kehidupan Beragama dan Sarana Ibadah (yang mencakup gangguan terhadap penyelenggaraan ibadah dan kegiatan keagamaan dan perusakan tempat ibadah). Kebijakan formulasi delik agama tersebut masih banyak mengandung kelemahan sehingga akan berpengaruh terhadap tahap aplikasi dan eksekusinya dalam praktik berhukum di Indonesia. Dalam kaitannya dengan delik agama, penggunaan sanksi pidana tentu harus memperhatikan rambu-rambu penggunaan pidana dan harus dilakukan dengan tujuan melakukan prevensi umum dan prevensi khusus. Oleh karena itu, hasil penelitian ini diharapkan dapat menjadi bahan masukan bagi penyempurnaan kebijakan formulasi RKUHP versi tahun 2015 khususnya yang berkaitan dengan delik agama. Penelitian ini menggunakan metode penelitian hukum normatif (yuridis normatif) dengan melakukan studi bahan kepustakaan guna mengumpulkan data sekunder dan dilakukan penafsiran dengan menggunakan pendekatan undang-undang, perbandingan hukum, sejarah hukum, asas hukum dan teori hukum.

Kata Kunci: Kebijakan Formulasi, Delik Agama, Rancangan KUHP.

\section{A. PENDAHULUAN}

Sila pertama dari Pancasila sebagai falsafah hidup, jiwa, pandangan hidup, pedoman dan kepribadian bangsa Indonesia sekaligus menjadi falsafah berbangsa dan Negara serta menjadi sumber dari segala sumber hukum di Indonesia adalah "Ketuhanan Yang Maha $E s a^{\prime \prime}$. Ini berarti, Indonesia adalah salah satu negara yang menempatkan agama sebagai sendi utama dalam kehidupan bermasyarakat, berbangsa dan bernegara. Agama merupakan hal fundamental dalam kehidupan di Indonesia karena pada kenyataannya, bangsa Indonesia 
adalah negara berTuhan dan memiliki filosofi Ketuhanan yang mendalam. ${ }^{1}$

Dikaitkan dengan konsep Indonesia sebagai Negara hukum, ${ }^{2}$ kedudukan agama sebagai sendi utama dalam kehidupan bermasyarakat, berbangsa dan bernegara tersebut dijelaskan lebih lanjut dalam ketentuan atau isi dalam Undang-Undang Dasar 1945 sebagai konstitusi Negara yakni dalam Bab XA yang mengatur mengenai Hak Asasi Manusia tepatnya dalam pasal 28E ayat (1) dan ayat (2) dan Bab XI yang mengatur tentang Agama tepatnya dalam pasal 29 ayat (1) dan ayat (2) yang berbunyi sebagai berikut:

\section{Pasal 28E UUD 1945:}

(1) Setiap orang bebas memeluk agama dan beribadat menurut agamanya, memilih pendidikan dan pengajaran, memilih pekerjaan, memilih kewarganegaraan, memilih tempat tinggal di wilayah negara dan meninggalkannya, serta berhak kembali.

(2) Setiap orang berhak atas kebebasan meyakini kepercayaan, menyatakan pikiran dan sikap sesuai dengan hati nuraninya. (cetak miring oleh penulis)

\section{Pasal 29 UUD 1945:}

(1) Negara berdasar atas Ketuhanan Yang Maha Esa.

(2) Negara menjamin kemerdekaan tiap-tiap penduduk untuk memeluk agamanya masing-masing dan untuk beribadah menurut agamanya dan kepercayaannya itu.

Dengan demikian, dalam konteks kehidupan umat beragama, negara memiliki kewajiban untuk menjamin kemerdekaan bagi setiap orang untuk memeluk agamanya masing-masing dan untuk beribadat menurut agama dan kepercayaannya itu sebagai salah satu perlindungan hak asasi manusia yang tidak dapat dikurangi dalam keadaan apapun. ${ }^{3}$

1 Bangsa Indonesia memiliki filosofi Ketuhanan yang sangat mendalam. Hal ini dapat ditemukan diantaranya dalam pandangan nenek moyang yang menyatakan bahwa ada kehidupan setelah kematian, adanya kepercayaankepercayaan kekuatan diluar manusia, dan lain sebagainya. Selain itu, sebagai bukti bahwa bangsa Indonesia memiliki filosofi Ketuhanan yang sangat mendalam dapat ditemukan dalam pembukaan Undang-Undang Dasar 1945 alinea ke tiga yang menyatakan bahwa: “ ... atas kehendak rahmat Allah Yang Maha Kuasa dan dengan didorongkan oleh keinginan luhur, supaya berkehidupan kebangsaan yang bebas, maka rakyat Indonesia menyatakan dengan ini kemerdekaannya ..." (cetak tebal dan miring oleh penulis)

2 Indonesia sebagai Negara hukum diatur secara tegas dalam ketentuan Pasal 1 angka 3 Undang-Undang Dasar 1945 amandemen ke empat yang menyatakan: "Indonesia adalah negara hukum".

3 Kemerdekaan untuk memeluk agama dan untuk beribadat menurut agama dan kepercayaannya masingmasing merupakan salah satu bentuk hak asasi manusia karena dalam Undang-Undang Republik Indonesia No. 39 Tahun 1999 tentang Hak Asasi Manusia disebutkan dengan tegas bahwa yang dimaksud dengan hak asasi manusia adalah seperangkat hak yang melekat pada hakikat dan keberadaan manusia sebagai mahluk Tugas Yang Mha Esa dan merupakan anugrah-Nya yang wajib dihormati, dijunjung tinggi dan dilindungi oleh negara hukun, Pemerintahan, dan setiap orang demi kehormatan serta perlindungan harkat dan martabat manusia 
Hal tersebut diatur secara tegas dalam ketentuan Pasal 28L ayat (1) UUD 1945 yang berbunyi: "Hak untuk hidup, hak untuk tidak disiksa, hak kemerdekaan pikiran dan hati nurani, hak beragama, hak untuk tidak diperbudak, hak untuk diakui sebagai pribadi di hadapan hukum, dan hak untuk tidak di tuntut atas dasar hukum yang berlaku surut adalah hak asasi manusia yang tidak dapat dikurangi dalam keadaan apapun" (cetak miring dan tebal oleh penulis).

Dalam Garis-Garis Besar Haluan Negara (GBHN), agama juga menempati posisi yang sentral. Pada Garis-Garis Besar Haluan Negara (GBHN) disebutkan bahwa Visi yang ingin dicapai adalah terwujudnya masyarakat Indonesia yang damai, demokratis, berkeadilan, berdaya saing, maju dan sejahtera, dalam wadah Negara Kesatuan Republik Indonesia yang didukung oleh manusia Indonesia yang sehat, mandiri, beriman, bertakwa, berakhlak mulia, cinta tanah air, berkesadaran hukum dan lingkungan menguasai ilmu pengetahuan dan teknologi, memiliki etos kerja yang tinggi serta berdisiplin. Selanjutnya, pada Misi Garis-Garis Besar Haluan Negara (GBHN) disebutkan bahwa untuk mewujudkan visi bangsa Indonesia masa depan, ditetapkan misi peningkatan pengamalan ajaran agama dalam kehidupan sehari-hari untuk mewujudkan kualitas keimanan dan ketaqwaan kepada Tuhan Yang Maha Esa dalam kehidupan dan mantapnya persaudaraan umat beragama yang berakhlak mulia, toleran, rukun dan damai (cetak miring dan tebal oleh penulis).

Selanjutnya, pada arah kebijakan Garis-Garis Besar Haluan Negara (GBHN) di bidang agama, disebutkan bahwa arah kebijakanya adalah sebagai berikut:

1. Memantapkan fungsi, peran, dan kedudukan agama sebagai landasan moral, spiritual, dan etika dalam penyelenggaraan negara serta mengupayakan agar segala peraturan perundang-undangan tidak bertentangan dengan moral agama-agama.

2. Meningkatkan kualitas pendidikan agama melalui penyempurnaan sistem pendidikan agama sehingga lebih terpadu dan integral dengan sistem pendidikan nasional dengan didukung oleh sarana dan prasarana yang memadai.

3. Meningkatkan dan memantapkan kerukunan hidup antarumat beragama sehingga tercipta suasana kehidupan yang harmonis dan saling menghormati dalam semangat kemajemukan melalui dialog antarumat beragama dan pelaksanaan pendidikan agama secara deskriptif yang tidak dogmatis untuk tingkat perguruan tinggi.

(Pasal 1 angka 1).

Dalam Pasal 22 Undang-Undang Republik Indonesia No. 39 Tahun 1999 tentang Hak Asasi Manusia juga diatur dengan tegas bahwa: "Setiap orang bebas memeluk agamanya masing-masing dan untuk beribadat menurut agamanya dan kepercayaannya itu" dan "Negara menjamin kemerdekaan setiap orang memeluk agamanya masing-masing dan untuk beribadat menurut agamanya dan kepercayaannya itu".

Berikutnya, Pasal 8 Undang-Undang Republik Indonesia No. 39 Tahun 1999 tentang Hak Asasi Manusia menegaskan bahwa: "Perlindungan, pemajuan, penegakan, dan pemenuhan hak asasi manusia menjadi tanggung jawab negara, terutama pemerintah". 
4. Meningkatkan kemudahan umat beragama dalam menjalankan ibadahnya, termasuk penyempurnaan kualitas pelaksanaan ibadah haji dan pengelolaan zakat, dengan memberikan kesempatan yang luas kepada masyarakat untuk berpartisipasi dalam penyelenggaraannya.

5. Meningkatkan peran dan fungsi lembaga-lembaga keagamaan dalam mengatasi dampak perubahan yang terjadi dalam semua aspek kehidupan untuk memperkukuh jati diri dan kepribadian bangsa serta memperkuat kerukunan hidup bermasyarakat, berbangsa dan bernegara.

Mengingat agama merupakan salah satu jiwa bangsa Indonesia, dijamin oleh konstitusi Negara Indonesia dan merupakan hak asasi manusia yang tidak dapat dikurangi dalam keadaan apapun serta bersifat penting maka wajar bila Negara memasukan atau menjadikan agama sebagai salah satu delik didalam hukum positifnya (hal ini dikenal dengan istilah "tindak pidana terhadap agama dan kehidupan beragama" atau dapat pula disebut dengan istilah “delik agama”). (Oemar Seno Adji 1981)

Mengutip pendapat dari pakar hukum pidana dari Universitas Diponegoro, Muladi menyatakan bahwa pengaturan tentang tindak pidana terhadap agama dan kehidupan beragama atau "delik agama" di Indonesia merupakan refleksi bahwa Indonesia merupakan 'Nation State' yang religius'. (Muladi 2004) Terkait dengan hal ini, Soehino menyatakan bahwa salah satu karakteristik dari Negara hukum Pancasila adalah religious nation state yakni dalam melihat hubungan antara negara dan agama maka konsep negara hukum Pancasila tidaklah menganut sekulerisme tetapi juga bukan sebuah negara agama seperti dalam teokrasi dan dalam konsep Nomokrasi Islam. (Soehino 1985) Konsep negara hukum Pancasila adalah sebuah konsep negara yang berketuhanan. Berketuhanan disini dapat diartikan bahwa kehidupan bermasyarakat, berbangsa dan bernegara Indonesia wajib didasarkan atas kepercayaan kepada Ketuhanan Yang Maha Esa, dengan begitu maka terbukalah suatu kebebasan bagi warga negara untuk memeluk agama dan kepercayaan sesuai keyakinannya masing-masing. Konsekuensi logis pilihan prismatik ini adalah atheisme dan juga komunisme dilarang karena telah mengesampingkan kepercayaan terhadap Tuhan Yang Maha Esa. (Soehino 1985)

Dalam konsep 'Nation State' yang religius' tersebut maka semua agama (religion) yang diakui sah di Indonesia merupakan kepentingan hukum yang besar yang harus dilindungi dan tidak sekedar merupakan bagian dari ketertiban umum yang mengatur tentang rasa keagamaan atau ketenteraman hidup beragama. (Muladi 2004) Pengaturan dan perlindungan terhadap tindak pidana terhadap agama dan kehidupan beragama, menunjukkan bahwa Indonesia memang bukan Negara yang berdasarkan atas agama, tetapi juga bukan negara sekuler, melainkan Negara yang berKetuhanan Yang Maha Esa.

al-ạ̣kān Vol. 3, Nomor 1, 2018 
Mardjono Reksodiputro dalam bukunya yang berjudul "Pembaharuan Hukum Pidana: Buku Keempat", menjelaskan lebih lanjut mengenai pentingnya pengaturan mengenai tindak pidana terhadap agama dan kehidupan beragama atau "delik agama" karena penghinaan terhadap suatu agama yang diakui di Indonesia ataupun cara-cara lain yang mengganggu kehidupan beragama akan membahayakan kedamaian hidup bermasyarakat dan kesatuan bangsa. (Mardjono Reksodiputro 1995)

Dengan adanya kepentingan hukum yang harus dilindungi dan adanya penghinaan atau hal-hal lainnya yang dapat mengganggu kehidupan beragama serta membahayakan kedamaian hidup bermasyarakat dan kesatuan bangsa, maka sudah sewajarnya tindak pidana terhadap agama dan kehidupan beragama atau delik agama yang mencakup pengaturan tindak pidana terhadap agama (offenses against religion) dan tindak pidana yang berkaitan dengan agama (offenses related religion) (Muladi 1988) menjadi suatu prioritas yang harus dilindungi oleh hukum pidana khususnya dalam rangka pembaharuan Kitab Undang-Undang Hukum Pidana Nasional.

Namun demikian, terdapat beberapa pihak yang menolak atau keberatan jika tindak pidana terhadap agama dan kehidupan beragama atau delik agama ini dimasukan dalam Kitab Undang-Undang Hukum Pidana Nasional yang baru dengan alasan banyak pasal dalam Rancangan Kitab Undang-Undang Hukum Pidana (RKUHP) yang akan menjadi over criminalization. Adapula yang beranggapan bahwa persoalan keagamaan merupakan wilayah privat dan tidak mesti semua perkara agama harus masuk dalam hukum (sebagai tindak pidana). Disisi yang lain, persoalan agama merupakan persoalan yang sangat sensitif dan dapat menjadi faktor yang menghancurkan persatuan dan kesatuan bangsa Indonesia. Pengaturan mengenai tindak pidana terhadap agama dan kehidupan beragama juga dirasa penting dalam rangka menciptakan perdamaian, kerukunan, ketentraman, kesejahteraan (baik secara materil maupun spirituli), keadilan sosial dan terciptanya stabilitas dan ketahanan nasional.

Berdasarkan uraian singkat diatas, pada tulisan ini akan dibahas kebijakan formulasi delik agama dalam Kitab Undang-Undang Hukum Pidana yang baru yakni Rancangan Kitab Undang-Undang Hukum Pidana (RKUHP) versi tahun 2015.

\section{B. METODE PENELITIAN}

Mengingat fokus utama penelitian ini membahas mengenai kebijakan formulasi delik agama dalam kitab undang-undang hukum pidana yang baru, maka penelitian ini dilakukan dengan menggunakan metode penelitian hukum normatif (yuridis normatif) dengan melakukan studi bahan kepustakaan guna mengumpulkan data sekunder. Sumber data sekunder tersebut mencakup bahan hukum primer, bahan hukum sekunder dan bahan hukum tertier. Bahan hukum primer yaitu bahan-bahan hukum yang mengikat, terdiri 
dari peraturan dasar (Undang-Undang Dasar 1945) dan peraturan perundang-undangan yang menyangkut topik dan materi penelitian. Bahan hukum sekunder (yang memberikan penjelasan mengenai bahan hukum primer) yang dipergunakan dalam penelitian ini berupa rancangan undang-undang, bahan-bahan seminar, simposium, diskusi panel, hasil penelitian dan beberapa literatur yang berkaitan dengan topik dan materi penelitian serta bahan hukum tertier, yakni bahan hukum yang memberikan petunjuk maupun penjelasan terhadap bahan hukum primer dan bahan hukum sekunder yaitu kamus, ensiklopedia yang berhubungan dengan materi penelitian. (Soerjono Soekanto dan Sri Mamudji 1985)Setelah semua data terkumpul, dilakukan penafsiran dengan menggunakan pendekatan undangundang, perbandingan hukum, sejarah hukum, asas hukum dan teori hukum dan hasil penelitian dijabarkan dengan metode kualitatif.

\section{PEMBAHASAN}

\section{Kebijakan Formulasi}

Menetapkan tindak pidana terhadap agama dan kehidupan beragama atau "delik agama" dalam peraturan perundang-undangan tentunya tidak dapat dilepaskan dari kebijakan formulasi atau kebijakan legislasi sebagai bagian dari upaya penanggulangan kejahatan dengan menggunakan sarana hukum pidana (penal policy) yang tujuannya tidak lain dan tidak bukan adalah untuk menciptakan perlindungan masyarakat (social deffance) dan kesejahteraan masyarakat (social wealfare). ${ }^{4}$

Tahap formulasi merupakan tahap yang paling strategis dari keseluruhan proses kebijakan untuk mengoperasionalisasikan atau memfungsionalisasikan peraturan perundang-undangan (khususnya dalam rangka penanggulangan kejahatan). Dikatakan demikian karena pada tahap ini dirumuskan garis-garis kebijakan dan padanya terdapat proses kriminalisasi dan proses penalisasi yang akan menjadi landasan legalitas (sebagai tolok ukur dalam menentukan atau mengetahui secara pasti dan jelas mengenai perbuatan yang dilarang dan diancam dengan pidana). Hal ini juga tentunya akan berpengaruh atau mempengaruhi tahap aplikasi dan eksekusinya dalam praktik berhukum.

Muladi dan Barda Nawawi Arief dalam bukunya yang berjudul "Teori-Teori dan Kebijakan Hukum Pidana" menyatakan bahwa: "Tahap penetapan pidana menurut hemat kami justru harus merupakan tahap perencanaan yang matang mengenai kebijakan-

4 Dalam konteks Indonesia, perlindungan masyarakat (social defence) dan kesejahteraan masyarakat (social wealfare) ini terkandung dalam alinea ke 4 pembukaan Undang-Undang Dasar 1945 yang mengatur mengenai tujuan nasional bangsa Indonesia yaitu: membentuk negara Indonesia yang melindungi segenap bangsa dan seluruh tumpah darah Indonesia dan untuk memajukan kesejahteraan umum, mencerdaskan kehidupan bangsa dan ikut melaksanakan ketertiban dunia yang berdasarkan kemerdekaan, perdamaian abadi dan keadilan sosial.

al-aḥkām vol. 3, Nomor 1, 2018 
kebijakan tindakan apa yang seharusnya diambil dalam hal pemidanaan apabila terjadi suatu pelanggaran hukum. Dengan perkataan lain, tahap ini harus merupakan tahap perencanaan strategis dibidang pemidanaan yang diharapkan dapat memberi arah pada tahap-tahap berikutnya, yaitu tahap penerapan pidana dan tahap pelaksanaan pidana". (Muladi dan Barda Nawawi Arief 1998) Oleh karena itu, kesalahan-kesalahan atau kelemahan-kelamahan pada kebijakan formulasi dapat dipandang sebagai kesalahan strategis dan oleh karenanya dapat menghambat atau setidak-tidaknya mempengaruhi efektivitas penanggulangan kejahatan dengan hukum pidana. (Barda Nawawi Arief 2003)

Sebagaimana telah dikemukakan, pada tahap formulasi ini terdapat proses kriminalisasi (dan proses penalisasi). Menurut Sudarto, yang dimaksud dengan kriminalisasi adalah proses penetapan suatu perbuatan orang sebagai perbuatan yang dapat dipidana. Proses ini diakhiri dengan terbentuknya undang-undang dimana perbuatan itu diancam dengan suatu sanksi yang berupa pidana. (Sudarto 1977) Setiap perbuatan yang dikriminalisasikan tentunya harus mempertimbangkan banyak hal / banyak faktor, karena proses kriminalisasi merupakan permasalahan sentral dalam kebijakan penanggulangan kejahatan dengan menggunakan sarana hukum pidana, selain masalah dalam penetapan sanksi yang sebaiknya dijatuhkan (proses penalisasi). (Barda Nawawi Arief 2002)

Menurut Barda Nawawi Arief, terdapat beberapa pertimbangan atau alasan kriminalisasi yang ditemukan dalam perundang-undangan di Indonesia. Alasan-alasan tersebut adalah sebagai berikut: (Barda Nawawi Arief 2000)

1. Tindakan tersebut bertentangan dengan kesusilaan, agama dan moral Pancasila;

2. Tindakan tersebut membahayakan kehidupan masyarakat, bangsa dan negara; dan

3. Tindakan tersebut menghambat tercapainya pembangunan nasional.

Bassiouni, menyatakan bahwa keputusan untuk melakukan kriminalisasi dan dekriminalisasi harus didasarkan pada faktor-faktor kebijakan tertentu, diantaranya: (Barda Nawawi Arief 2000)

1. Keseimbangan sarana-sarana yang digunakan dalam hubungannya dengan hasilhasil yang ingin dicapai.

2. Analisis biaya terhadap hasil-hasil yang diperoleh dalam hubungannya dengan tujuan-tujuan yang dicari.

3. Penilaian atau penafsiran tujuan-tujuan yang dicari itu dalam kaitannya dengan prioritas-prioritas lainnya dalam pengalokasian sumber-sumber tenaga manusia.

4. Pengaruh sosial dari kriminalisasi dan dekriminalisasi yang dipandang dari pengaruhpengaruhnya yang sekunder.

Lebih lanjut dikemukakan oleh Bassiouni, bahwa proses kriminalisasi yang berlangsung terus tanpa suatu evaluasi mengenai pengaruhnya terhadap keseluruhan 
sistem akan mengakibatkan timbulnya krisis kelebihan kriminalisasi (the crisis of over criminalization), yakni banyaknya atau melimpahnya jumlah kejahatan dan perbuatan yang dikriminalisasikan serta krisis kemampuan batas dari hukum pidana (the crisis of overreach of the criminal law), yakni usaha pengendalian yang tidak menggunakan sanksi yang efektif. (Barda Nawawi Arief 2002)

Selain itu, dalam melakukan proses kriminalisasi seyogianya diperhatikan beberapa kriteria kriminalisasi dan dekriminalisasi sebagaimana termuat dalam laporan Simposium Pembaharuan Hukum Pidana Nasional yang diselenggarakan pada bulan Agustus tahun 1980 di Semarang, beberapa kriteria tersebut antara lain sebagai berikut:

1) Apakah perbuatan itu tidak disukai atau dibenci oleh masyarakat karena merugikan, atau dapat merugikan, mendatangkan korban atau dapat mendatangkan korban.

2) Apakah biaya mengkriminalisasi seimbang dengan hasil yang akan dicapai, artinya cost pembuatan undang-undang, pengawasan dan penegakan hukum, serta beban yang dipikul oleh korban dan pelaku kejahatan itu sendiri harus seimbang dengan tertib hukum yang akan dicapai.

3) Apakah akan makin menambah beban aparat penegak hukum yang tidak seimbang atau nyata-nyata tidak dapat diemban oleh kemampuan yang dimilikinya.

4) Apakah perbuatan-perbuatan itu menghambat atau menghalangi cita-cita bangsa, sehingga merupakan bahaya bagi keseluruhan masyarakat.

\section{Kebijakan Formulasi Delik Agama Dalam Rancangan Kitab Undang-Undang Hukum Pidana Versi Tahun 2015}

Upaya pembaharuan hukum pidana nasional telah dimulai sejak tahun 1963. Usaha pembaharuan Kitab Undang-Undang Hukum Pidana (KUHP) nasional tersebut telah beberapa kali dilakukan dengan diterbitkannya Rancangan Kitab Undang-Undang Hukum Pidana (RKUHP) dan yang terakhir, telah diterbitkan Rancangan Kitab Undang-Undang Hukum Pidana (RKUHP) nasional versi tahun 2015. Dalam Rancangan Kitab Undang-Undang Hukum Pidana (RKUHP) nasional versi tahun 2015 tersebut telah diatur secara tegas mengenai tindak pidana terhadap agama dan kehidupan beragama atau delik-delik agama.

Pengaturan mengenai tindak pidana terhadap agama dan kehidupan beragama dalam Rancangan Kitab Undang-Undang Hukum Pidana (RKUHP) nasional versi tahun 2015 mengacu kepada perkembangan "blasphemy" di Inggris atau perkembangan "Godslasteringswet" di Belanda. "Blasphemy" dan "Godslasteringswet" sendiri secara sederhana dapat dimaknai sebagai tindakan menghina keagungan Tuhan, firman dan sifat-sifat Ketuhanan. Mengenai hal ini, di Inggris sendiri pengaturan hukum "blasphemy" mengandung kelemahan mendasar dan menyebabkan pengaturan mengenai "blasphemy" 
ini mendapat banyak kritikan. Kelemahan yang dimaksud yakni perlindungan hukum hanya diberikan pada agama tertentu (agama Kristen saja) karena di Inggris, agama Kristen di anggap sebagai bagian yang sangat penting dalam struktur masyarakat. ("Draf Naskah Akademik Rancangan Undang-Undang Tentang Kitab Undang-Undang Hukum Pidana (KUHP)" 2015) Hal ini nampak pada "actus reus" blasphemy yang dirumuskan sebagai berikut: ".... if it denies the truth of the Cristionan religion or of the Bible or the Book of Common Prayer, or the existence of God". ("Draf Naskah Akademik Rancangan UndangUndang Tentang Kitab Undang-Undang Hukum Pidana (KUHP)" 2015). Oleh karenanya, muncul kritikan untuk juga melindungi kepentingan hukum agama-agama lain serta atas dasar kenyataan, bahwa selama lebih dari seratus tahun jarang sekali orang dituntut karena telah melakukan "blasphemy". ${ }^{5}$ (Aliansi Nasional Reformasi KUHP 2015) dan (Barda Nawawi Arief 2007)

Dalam melakukan kriminalisasi terhadap delik agama, terdapat setidaknya 3 (tiga) teori sebagaimana dikemukakan oleh Oemar Seno Adji dan dikutip kembali oleh Barda Nawawi Arief yang pada intinya menyatakan sebagai berikut: (Barda Nawawi Arief 2007)

1. Religionsschutz Theorie (Teori Perlindungan Agama)

Menurut teori ini, agama sendiri dilihat sebagai kepentingan hukum atau objek yang akan dilindungi (yang dipandang perlu untuk dilindungi) oleh negara, melalui peraturan perundang-undangan yang dibuatnya.

2. Gefuhlsschutz Theorie (Teori Perlindungan Perasaan Keagamaan)

Menurut teori ini, kepentingan hukum yang akan dilindungi adalah rasa atau perasaan keagamaan dari orang-orang yang beragama.

3. Friedensschutz Theorie (Teori Perlindungan Perdamaian atau Teori Perlindungan Ketentraman Umat Beragama).

5 Oleh karena itu, The Law Commission di dalam kertas kerjanya (1981) telah memberikan rekomendasi agar peraturan hukum tentang "blasphemy" digantikan dengan "an offence of using threatening, abusive or insulting words or behaviour at any time in any place of worship of the Church of England, or in any other certified place of religious worship, in any churchyard or burial ground, with intent to wound or outrage the feelings of those using the premises concerned".

Dalam tataran praktik, delik ini sulit dibuktikan. Hal ini terjadi karena terdapat kesulitan membuktikan unsur mens rea. Hal ini memang menjadi salah satu alasan mengapa penuntutan-penuntutan kasus blasphemy di Inggris sangat jarang terjadi.

Sebagai bahan perbandingan, di Kanada, delik Godslasteringswet (Belanda) dan Blashphemy (Inggris) dirumuskan dalam ketentuan Pasal 286 KUHP Kanada yang mengatur mengenai Blasphemous Libel. Ketentuan tersebut berbunyi:

Every one who publishes a blasphemous libel is guilty of an incitable offence and liable to imprisonment for a term not exceeding two years;

It is a question of fact whether or not any matter that is published is a blasphemous libel;

No person shall be convicted of an offence under this section for expressing in good faioth and decent language, or attempting to establish by argument used in good faith and conveyed in decent language, an opinion on a religious subject. 
Objek atau kepentingan hukum yang dilindungi menurut teori ini adalah "kedamaian atau keteraman beragama interkonfesional diantara pemeluk agama atau kepercayaan. Dalam bahasa Jerman, hal ini disebut dengan istilah "der religios interkonfessionelle Friede". Dengan demikian, hal ini lebih ditunjukan kepada perlindungan ketertiban umum.

Tindak pidana terhadap agama dan kehidupan beragama atau delik agama dalam Rancangan Kitab Undang-Undang Hukum Pidana (RKUHP) nasional versi tahun 2015 diatur secara tegas dalam Bab VII yang mengatur mengenai Tindak Pidana Terhadap Agama dan Kehidupan Beragama. Pentingnya pengaturan tentang tindak pidana agama ini karena hal ini merupakan pewujudan dari sila pertama dalam Pancasila, yaitu Ketuhanan Yang Maha Esa, yang berarti bahwa dalam masyarakat Indonesia agama merupakan sendi utama dalam hidup bermasyarakat, berbangsa dan bernegara. Perbuatan yang dilarang di sini adalah perbuatan tercela dengan tidak menghormati agama atau umat beragama yang dapat menimbulkan keresahan dalam masyarakat, atau umat beragama yang bersangkutan, termasuk terhadap sarana ibadah. ("Draf Naskah Akademik Rancangan Undang-Undang Tentang Kitab Undang-Undang Hukum Pidana (KUHP)" 2015)

Dalam Bab VII Rancangan Kitab Undang-Undang Hukum Pidana (RKUHP) nasional versi tahun 2015, pengaturan tindak pidana terhadap agama dan kehidupan beragama atau delik agama dikelompokan kembali menjadi beberapa kelompok yaitu sebagai berikut:

1) Tindak Pidana Terhadap Agama:

a. Penghinaan Terhadap Agama (Pasal 341 sampai dengan Pasal 344 RKUHP)

b. Penghasutan Untuk Meniadakan Keyakinan Terhadap Agama (Pasal 345 RKUHP)

2) Tindak Pidana Terhadap Kehidupan Beragama dan Sarana Ibadah:

a. Gangguan Terhadap Penyelenggaraan Ibadah Dan Kegiatan Keagamaan (Pasal 346 dan Pasal 347 RKUHP)

b. Perusakan Tempat Ibadah (Pasal 348 RKUHP).

Perlu kiranya disampaikan pada bagian ini bahwa pengaturan delik agama dalam Rancangan Kitab Undang-Undang Hukum Pidana (RKUHP) nasional versi tahun 2015 sebenarnya merupakan perluasan delik yang telah diatur dalam Pasal 156 huruf a Kitab Undang-Undang Hukum Pidana dan Undang-Undang No. 1 PNPS Tahun 1965. Adapun kebijakan formulasi tindak pidana terhadap agama dan kehidupan beragama atau delik agama dalam Rancangan Kitab Undang-Undang Hukum Pidana (RKUHP) nasional versi tahun 2015 tersebut berbunyi sebagai berikut:

al-ạ̣kām Vol. 3, Nomor 1, 2018 


\section{Pasal 341 RKUHP:}

Setiap orang yang di muka umum menyatakan perasaan atau melakukan perbuatan yang bersifat penghinaan terhadap agama yang dianut di Indonesia, dipidana dengan pidana penjara paling lama 2(dua) tahun atau pidana denda paling banyak Kategori III.

Dalam penjelasannya ditegaskan bahwa sila pertama dari falsafah negara Pancasila adalah Ketuhanan Yang Maha Esa. Ini berarti agama, bagi masyarakat Indonesia merupakan sendi utama dalam hidup bermasyarakat. Oleh karena itu, penghinaan terhadap suatu agama yang dianut di Indonesia patut dipidana karena dinilai tidak menghormati dan menyinggung perasaan keagamaan dalam masyarakat.

Ketentuan ini dapat dipandang sebagai ketentuan yang lebih ditujukan untuk melindungi kesucian agama yang dianut seseorang atau golongan tertentu. (Aliansi Nasional Reformasi KUHP 2015)Dikatakan demikian karena pengaturan ini tentu saja ditujukan untuk melindungi kesucian agama-agama yang diakui secara tegas oleh Negara (Islam, Hindu, Budha, Konghucu, Kristen Protestan dan Kristen Katholik). Sementara perlindungan terhadap keyakinan atau kepercayaan lain tidak diberikan dengan baik, bahkan tidak diberikan perlindungan sama sekali (seperti misalnya aliran Ahmadiyah, Eden dan sebagainya). Padahal, keyakinan untuk beragama atau meyakini aliran tertentu, adalah hak yang paling mendasar yang dijamin dalam instrumen hak asasi manusia. (Aliansi Nasional Reformasi KUHP 2015)Pasal ini sangat berpotensi digunakan secara subjektif oleh agama tertentu yang dicatat di Indonesia, sehingga sangat diskriminatif. (Aliansi Nasional Reformasi KUHP 2015)

Penggunaan unsur "penghinaan" dalam ketentuan tersebut juga menjadi masalah karena tidak tegas pembatasan perbuatannya dan tidak limitatif, sehingga rumusannya menjadi sangat kabur. Dalam kajian hukum pidana dan hak kebebasan beragama, "penghinaan" menjadi sulit untuk diukur secara materil, sehingga pembuktiannya sangat sulit untuk dilakukan (karena hal ini akan tergantung subyektifitas seseorang). Subyektifitas seseorang ini menjadi sangat berbahaya dalam konteks hukum pidana, karena bersifat "karet" dan dapat disalahgunakan untuk hal-hal di luar kepentingan hukum. (Aliansi Nasional Reformasi KUHP 2015)

\section{Pasal 342 RKUHP:}

Setiap orang yang di muka umum menghina keagungan Tuhan, firman dan sifat-Nya, dipidana dengan pidana penjara paling lama 5 (lima) tahun atau pidana denda paling banyak Kategori IV.

Penjelasannya menyatakan bahwa menghina Ke-Agungan Tuhan, Firman, dan sifat-Nya, merupakan penghinaan secara tidak langsung terhadap umat yang 
menghormati Ke-Agungan Tuhan, Firman, dan sifat-Nya, dan dapat menimbulkan keresahan dalam kelompok umat yang bersangkutan. Di samping mencela perbuatan penghinaan tersebut, Pasal ini bertujuan pula untuk mencegah terjadinya keresahan dan benturan dalam dan di antara kelompok masyarakat.

Perlu dikemukakan bahwa ketentuan ini merupakan ketentuan yang serupa dengan pengaturan mengenai Godslasteringswet di Belanda dan Blashphemy di Inggris sebagaimana telah diuraikan pada bagian sebelumnya. Terhadap ketentuan tersebut, istilah "penghinaan terhadap agama" yang ditafsirkan sebagai "menghina Ke-Agungan Tuhan, Firman dan sifat-sifatNya", bersifat ambigu, tidak jelas, serta tidak ada pengertian serta batasan yang jelas sehingga dapat menimbulkan keresahan dalam kelompok umat yang bersangkutan. (Aliansi Nasional Reformasi KUHP 2015). Peristilahan-peristilahan tersebut masih sangat luas interpretasinya sehingga dapat sangat bersifat subjektif. Setiap orang akan dengan mudah dituduh dengan alasan menghina keagungan Tuhan, firman dan sifatNya. Tentu saja hal ini menjadi problematis dalam penegakan hukumnya. Hal ini juga dapat merupakan perbenturan dengan jaminan konstitusi mengenai kebebasan berpikir dan berekspresi. (Aliansi Nasional Reformasi KUHP 2015). Dalam rumusan pasal 342 RKUHP tersebut diatas, menurut hemat penulis juga perlu dirumuskan sebagai delik materiil yakni dengan mencantumkan secara tegas mengenai dampak dari tindak pidana yang dihasilkan berupa "menimbulkan keresahan dan benturan dalam kelompok umat yang bersangkutan maupun dalam masyarakat".

\section{Pasal 343 RKUHP:}

Setiap orang yang di muka umum mengejek, menodai, atau merendahkan agama, rasul, nabi, kitab suci, ajaran agama, atau ibadah keagamaan, dipidana dengan pidana penjara paling lama 5 (lima) tahun atau pidana denda paling banyak Kategori IV.

Pada penjelasannya dinyatakan bahwa mengejek, menodai atau merendahkan Agama, Rasul, Nabi, Kitab Suci, Ajaran, dan Ibadah Keagamaan harus dianggap sebagai perbuatan yang dapat merusak kerukunan hidup beragama dalam masyarakat Indonesia, dan karena itu harus dilarang dan diancam pidana.

Demikian pula dengan ketentuan ini, tidak ada pengertian dan batasan yang jelas mengenai "mengejek, menodai, atau merendahkan agama, rasul, nabi, kitab suci, ajaran agama, atau ibadah keagamaan". Hal semacam itu dapat bertentangan dan mengancam hak atas kebebasan berpikir dan berekspresi sebagaimana telah diatur dalam konstitusi dan Undang-Undang Republik Indonesia No. 39 tahun 1999 tentang Hak Asasi Manusia. Dengan pengaturannya yang demikian, dapat mengakibatkan orang dengan mudah diseret ke pengadilan. (Aliansi Nasional Reformasi KUHP 2015). Selain itu, pengaturan yang tidak membatasi terminologi "mengejek, menodai, atau merendahkan" dapat pula berpeluang 
atau menciptakan potensi konflik dalam masyarakat. (Aliansi Nasional Reformasi KUHP 2015). Berkaitan dengan akibat dari tindak pidana, menurut hemat penulis, akibat berupa "rusaknya kerukunan hidup beragama dalam masyarakat Indonesia" seyogianya dicantumkan dalam rumusan delik Pasal 343 RKUHP tersebut diatas (tidak hanya dirumuskan dalam penjelasan melainkan sebagai unsur tindak pidana).

\section{Pasal 344 RKUHP:}

(1) Setiap orang yang menyiarkan, mempertunjukkan atau menempelkan tulisan atau gambar, sehingga terlihat oleh umum, atau memperdengarkan suatu rekaman sehingga terdengar oleh umum, yang berisi tindak pidana sebagaimana dimaksud dalam Pasal 341 atau Pasal 343, dengan maksud agar isi tulisan, gambar, atau rekaman tersebut diketahui atau lebih diketahui oleh umum, dipidana dengan pidana penjara paling lama 7 (tujuh) tahun atau pidana denda paling banyak Kategori IV.

(2) Jika pembuat tindak pidana sebagaimana dimaksud pada ayat (1) melakukan perbuatan tersebut dalam menjalankan profesinya dan pada waktu itu belum lewat 2 (dua) tahun sejak adanya putusan pemidanaan yang telah memperoleh kekuatan hukum tetap karena melakukan tindak pidana yang sama maka dapat dijatuhi pidana tambahan berupa pencabutan hak sebagaimana dimaksud dalam Pasal 91 ayat (1) huruf $g$.

Terhadap ketentuan diatas, dapat diberikan catatan bahwa tujuan dari dilakukannya tindak pidana harus diperjelas sehingga ketentuan tersebut tidak disalahgunakan. Tujuan dari dilakukannya tindak pidana itu diantaranya memunculkan gangguan ketertiban umum (diukur misalnya dengan adanya kekerasan massal dan konflik), mengganggu ketertiban dan keharmonisan kehidupan keagamaan dan lain sebagainya. (Aliansi Nasional Reformasi KUHP 2015)

\section{Pasal 345 RKUHP:}

Setiap orang yang di muka umum menghasut dalam bentuk apapun dengan maksud meniadakan keyakinan terhadap agama yang sah dianut di Indonesia, dipidana dengan pidana penjara paling lama 4(empat) tahun atau pidana denda paling banyak Kategori IV.

Penjelasannya menyatakan bahwa penghasutan dilakukan dalam bentuk apapun, dengan tujuan agar pemeluk agama yang dianut di Indonesia menjadi tidak beragama.

Disamping tidak memberikan perlindungan terhadap keyakinan atau kepercayaan lain diluar agama yang diakui oleh Negara, dianutnya atau membuat dianutnya keyakinan atau kepercayaan lain di luar agama sah yang diakui oleh Negara (Islam, Hindu, Budha, 
Konghucu, Kristen Protestan, Kristen Katholik) dapat dipandang sebagai "meniadakan keyakinan agama yang dianut" dan dapat dipidana berdasarkan ketentuan ini. (Aliansi Nasional Reformasi KUHP 2015). Selain itu, perlu ditegaskan bahwa ketentuan ini mengatur mengenai ajakan atau hasutan untuk meninggalkan agama tertentu dengan cara-cara yang tidak benar dan tidak etis yang menyebabkan hilangkan kesadaran atau kemampuan obyek untuk memilih atas apa yang diyakininya secara bebas dan sadar. (Aliansi Nasional Reformasi KUHP 2015). Untuk itu, yang perlu dilihat bukan saja ajakan untuk meninggalkan agama, namun juga tindakan atau hasutan yang manipulatif dan tindakan tersebut menyebabkan orang (sasaran ajakan) tidak mampu memilih kecuali mengikuti apa yang dikehendaki oleh penghasut, baik karena faktor ekonomi, hubungan kerja atasan-bawahan, dan lain sebagainya. (Aliansi Nasional Reformasi KUHP 2015)

\section{Pasal 346 RKUHP:}

(1) Setiap orang yang mengganggu, merintangi, atau dengan melawan hukum membubarkan dengan cara kekerasan atau ancaman kekerasan terhadap jamaah yang sedang menjalankan ibadah, upacara keagamaan, atau pertemuan keagamaan, dipidana dengan pidana penjara paling lama 3 (tiga) tahun atau pidana denda paling banyak Kategori IV.

(2) Setiap orang yang membuat gaduh di dekat bangunan tempat untuk menjalankan ibadah pada waktu ibadah sedang berlangsung, dipidana dengan pidana denda paling banyak Kategori II.

Penjelasannya menyatakan bahwa perbuatan yang diatur dalam ketentuan Pasal ini diancam pidana lebih berat daripada perbuatan yang diatur dalam ketentuan Pasal 341 , karena secara langsung dapat menimbulkan benturan dalam dan di antara kelompok masyarakat.

Terkait dengan ketentuan diatas, kiranya perlu diperhatikan catatan dari Aliansi Nasional Reformasi KUHP yang menyatakan bahwa bagaimana mengukur "kegaduhan" ini? Pasal ini akan sangat ambigu dan multitafsir dan menjadi pasal "karet" ketika diterapkan. Kegaduhan dimaksud dalam pasal ini harus dibatasi di dalam ruang atau kompleks ibadah yang sedang berlangsung, sehingga ada batasan yang jelas mana yang dianggap mengganggu kekhidmatan ibadah.(Aliansi Nasional Reformasi KUHP 2015)

\section{Pasal 347 RKUHP:}

Setiap orang yang di muka umum mengejek orang yang sedang menjalankan ibadah atau mengejek petugas agama yang sedang melakukan tugasnya, dipidana dengan pidana penjara paling lama 2 (dua) tahun atau pidana denda paling banyak Kategori III. 
Penjelasannya menyatakan bahwa seorang atau umat yang sedang menjalankan ibadah atau seorang petugas agama yang sedang melakukan tugasnya harus dihormati. Karena itu, perbuatan mengejek atau mengolok-olok hal tersebut patut dipidana karena melanggar asas hidup bermasyarakat yang menghormati kebebasan memeluk agama dan kebebasan dalam menjalankan ibadah, di samping dapat menimbulkan benturan dalam dan di antara kelompok masyarakat.

Terkait dengan ketentuan diatas, Aliansi Nasional Reformasi KUHP memberikan catatan bahwa "petugas agama" tidak jelas pengaturannya, siapa saja dan dalam kewenangan apa saja seseorang dapat dikualifikasikan sebagai petugas agama. (Aliansi Nasional Reformasi KUHP 2015). Selain itu, perlu ditegaskan atau diberikan penjelasan lebih lanjut bahkan diatur sebagai unsur delik berkenaan dengan akibat dari tindak pidana ini, misalnya terjadinya benturan dalam dan di antara kelompok masyarakat atau kegaduhan dan keributan atau keonaran dalam masyarakat. (Aliansi Nasional Reformasi KUHP 2015)

\section{Pasal 348 RKUHP:}

Setiap orang yang menodai atau secara melawan hukum merusak atau membakar bangunan tempat beribadah atau benda yang dipakai untuk beribadah, dipidana dengan pidana penjara paling lama 5 (lima) tahun atau pidana denda paling banyak Kategori IV.

Penjelasannya menyatakan bahwa merusak, membakar, atau menodai (mengotori) bangunan atau benda ibadah merupakan perbuatan yang tercela, karena sangat menyakiti hati umat yang bersangkutan, oleh karena itu patut dipidana. Untuk dapat dipidana berdasarkan ketentuan dalam pasal ini, perbuatan tersebut harus dilakukan dengan melawan hukum. Dengan demikian, perusakan dan pembakaran harus dilakukan dengan melawan hukum.

Terkait dengan pasal 346 RKUHP sampai dengan pasal 348 RKUHP yang mengatur mengenai perlindungan dalam menjalankan agama yang diakui negara berkenaan dengan mengganggu, merintangi, membuat gaduh, mengejek, atau dengan melawan hukum membubarkan orang yang sedang menjalankan ibadah, upacara keagamaan dan sebagainya serta mengenai pengrusakan tempat ibadah, jaminan perlindungan hukum hanya diberikan untuk penganut agama-agama yang diakui oleh negara saja.(Aliansi Nasional Reformasi KUHP 2015). Oleh karena itu, terkait dengan hal ini perlu diperluas menjadi semua keyakinan dan agama yang ada di Indonesia (termasuk pula pengertian tempat ibadahnya). (Aliansi Nasional Reformasi KUHP 2015). Disamping itu, menurut hemat penulis, ketentuan tersebut perlu dirumuskan sebagai delik materiil yakni delik yang dianggap selesai manakala akibat dari tindak pidana yang dilakukan telah muncul (timbulnya benturan dalam dan di antara kelompok masyarakat). Dengan demikian, unsur ini perlu dirumuskan dengan tegas dalam rumusan tindak pidana. 
Berdasarkan beberapa ketentuan tersebut diatas (dengan segala kekurangan dan kelebihannya), dapat dilihat dengan jelas bahwa Rancangan Kitab Undang-Undang Hukum Pidana (RKUHP) nasional versi tahun 2015 telah mengatur dengan tegas dan jelas mengenai delik-delik agama yang termasuk dalam kriteria tindak pidana yang ditujukan terhadap agama dan tindak pidana yang berhubungan dengan agama atau tindak pidana terhadap kehidupan umat beragama.

\section{Rambu-Rambu Penggunaan Sanksi Pidana}

Sudarto menyatakan bahwa dalam penggunaan sanksi pidana harus diperhatikan hal-hal sebagai berikut: "Penggunaan hukum pidana harus memperhatikan tujuan pembangunan nasional, yaitu mewujudkan masyarakat adil dan makmur yang merata baik secara material maupun spiritual berdasarkan Pancasila" (Sudarto 1977). Berikutnya, Sudarto menyatakan beberapa hal yang harus diperhatikan dalam mempergunakan sanksi pidana. Beberapa hal tersebut yaitu sebagai berikut: (Sudarto 1977)

1) Penggunaan hukum pidana harus memperhatikan tujuan pembangunan nasional, yaitu mewujudkan masyarakat adil dan makmur yang merata baik secara material maupun secara spiritual berdasarkan Pancasila. Sehubungan dengan ini maka (penggunaan) hukum pidana bertujuan untuk menanggulangi kejahatan dan mengadakan pengugeran terhadap tindakan penanggulangan itu sendiri, demi kesejahteraan dan pengayoman masyarakat.

2) Perbuatan yang diusahakan untuk mencegah atau ditanggulangi dengan hukum pidana harus merupakan perbuatan yang tidak dikehendaki, yaitu perbuatan yang mendatangkan kerugian (material dan/atau spiritual) atas warga masyarakat.

3) Penggunaan hukum pidana harus pula memperhitungkan prinsip biaya dan hasil (cost and benefit principle).

4) Penggunaan hukum pidana harus pula memperhatikan kapasitas atau kemampuan daya kerja dari badan-badan penegak hukum, yaitu jangan sampai ada kelampauan beban tugas (overvelasting)

Salah satu prinsip dalam hukum pidana adalah tidak hanya melihat penderitaan korban atau penderitaan terpidana saja (not only for the person injured), tetapi juga harus melihat ketentraman masyarakat sebagai satu kesatuan yang utuh (Aliansi Nasional Reformasi KUHP 2015). Oleh karenanya, hukum pidana harus bersifat ultimum remidium, yaitu: sanksi yang berupa pidana dikenakan sebagai obat terakhir. Sanksi pidana diberikan, manakala sanksi-sanksi yang lain, misalnya sanksi perdata dan sanksi administrasi sudah tidak mampu lagi mengatasi permasalahan yang ada. (Aliansi Nasional Reformasi KUHP 2015)

al-ạ̣kām Vol. 3, Nomor 1, 2018 


\section{PENUTUP}

Negara Indonesia adalah Negara hukum berdasarkan Pancasila. Dengan demikian, terdapat urgensi untuk mengatur kehidupan dan kerukunan hidup antar umat beragama yang ada didalamnya mengingat negara Indonesia merupakan Negara yang multi agama, multi etnik dan multi ras. Pengaturan ini salah satunya dilakukan dengan mencantumkan delik-delik agama dalam Kitab Undang-Undang Hukum Pidana yang baru dan hal ini sematamata dilakukan untuk menghindari konflik-konflik antar umat beragama yang dalam jangka panjang dapat menghancurkan persatuan dan kesatuan bangsa Indonesia.

Upaya penanggulangan kejahatan dengan menggunakan hukum pidana merupakan cara yang paling tua setua peradaban manusia itu sendiri (older phylosophy of crime control) (Muladi dan Barda Nawawi Arief 1998). Dikaitkan dengan pembahasan makalah ini, delik agama memang telah diatur dalam Rancangan Kitab Undang-Undang Hukum Pidana (RKUHP) versi tahun 2015. Namun demikian, penggunaan sanksi pidana terhadap para pelakunya tetap harus memperhatikan rambu-rambu penggunaan sanksi pidana dan seyogianya menerapkan pendapat dari Jeremy Bentham yang menyatakan bahwa ketentuan pidana hendaknya tidak digunakan apabila "groundless, needless, unprofitable or inefficacious (Barda Nawawi Arief 1998). Demikian pula dengan H.L. Packer dalam bukunya yang berjudul "The Limits of Criminal Sanction" menyatakan bahwa: "the criminal sanction is once prime guarantor and prime threatener of human freedom. Used providently and humanely, it is guarantor; used indiscriminately and coercively, it is threatener (sanksi pidana suatu ketika merupakan penjamin yang utama/terbaik dan suatu ketika merupakan pengancam yang utama dari kebebasan manusia. la merupakan penjamin apabila digunakan secara hemat, cermat dan secara manusiawi; ia merupakan pengancam apabila digunakan secara sembarangan dan secara paksa) (Muladi dan Barda Nawawi Arief 1998). Ini artinya, pemidanaan harus dijadikan langkah terakhir (ultimatum remedium) dalam rangka mencapai tujuan yang sudah ditentukan (prevensi umum dan prevensi khusus). Oleh karena itu, menurut hemat penulis, pemidanaan terhadap pelaku delik agama tetap dimungkinkan selama dilakukan dengan memperhatikan rambu-rambu penggunaan sanksi pidana dan dilakukan sebagai sarana untuk mencapai tujuan yang telah ditentukan. 


\section{DAFTAR PUSTAKA}

\section{A. Buku.}

Aliansi Nasional Reformasi KUHP. 2015. Catatan Terhadap Beberapa Ketentuan Dalam Rancangan KUHP. Jakarta Selatan: Institute for Criminal Justice Reform.

Barda Nawawi Arief. 1998. Beberapa Aspek Kebijakan Penegakan Dan Pengembangan Hukum Pidana, Bandung. Bandung: Citra Aditya Bakti.

- - . 2000. Kebijakan Legislatif Dalam Penanggulangan Kejahatan Dengan Pidana Penjara. Semarang: Badan Penerbit Universitas Diponegoro.

-- - 2002. Bunga Rampai Kebijakan Hukum Pidana. Bandung: Citra Aditya Bakti.

- - . 2003. Kapita Selekta Hukum Pidana. Bandung: PT. Citra Aditya Bakti.

-- - 2007. Delik Agama Dan Penghinaan Tuhan (Blasphemy) Di Indonesia Dan Perbandingannya Di Berbagai Negara. Semarang: Badan Penerbit Universitas Diponegoro.

"Draf Naskah Akademik Rancangan Undang-Undang Tentang Kitab Undang-Undang Hukum Pidana (KUHP)." 2015. Jakarta.

Mardjono Reksodiputro. 1995. Pembaharuan Hukum Pidana: Buku Keempat. Jakarta: Pusat Pelayanan Keadilan dan Pengabdian Hukum Lembaga Kriminologi Universitas Indonesia.

Muladi. 1988. "Pembaharuan Hukum Pidana Yang Berkualitas Di Indonesia." Jurnal Majalah Masalah-Masalah Hukum, Fakultas Hukum Universitas Diponegoro 2.

- - . 2004. "Beberapa Catatan Berkaitan Dengan RUU KUHP Baru." Batam.

Muladi dan Barda Nawawi Arief. 1998. Teori-Teori Dan Kebijakan Hukum Pidana. Bandung: Alumni.

Oemar Seno Adji. 1981. Hukum (Acara) Pidana Dalam Prospeksi. Jakarta: Erlangga.

Soehino. 1985. Hukum Tata Negara: Negara Kesatuan Republik Indonesia Berdasarkan Pancasila Dan Undang-Undang Dasar 1945 Adalah Negara Hukum. Yogyakarta.

Soerjono Soekanto dan Sri Mamudji. 1985. Penelitian Hukum Normatif Suatu Tinjauan Singkat. Jakarta: CV Rajawali.

Sudarto. 1977. Hukum Dan Hukum Pidana. Bandung: Alumni.

\section{B. Peraturan Perundang-Undangan.}

Undang-Undang Dasar 1945 Pasca Amandemen.

Undang-Undang Republik Indonesia No. 39 Tahun 1999 tentang Hak Asasi Manusia. 